\title{
Parlementaire circulatie in de Belgische Kamer van volksvertegenwoordigers, 1831-2008
}

Frederik Verleden en Christophe Heyneman

\section{ABSTRACT \\ Legislative careers in the Belgian Chamber of Representatives 1831-2008}

This article examines legislative turnover and parliamentary career length in the Belgian Chamber of Representatives since Belgian independence in 1831 . Early on a stable representative elite emerged, characterized by a relatively low turnover and an average parliamentary career of nearly ten years. This pattern has changed substantially in the second half of the twentieth century. The average career length in the Chamber is nowadays historically low, due to some extent to the practice of level-hopping. The distribution of career lengths is at the same time highly asymmetrical. The literature on parliamentary careers and turnover suggests three major explanatory variables: regime change, the evolution of political parties and of the institutional framework. In the Belgian case institutional reform and regime change generated merely temporary effects. The same goes for the rise of the organised mass party at the end of the 19th century. The drop in average career length after the Second World War corresponds with a tighter hold of political parties on the selection process of parliamentary candidates.

KEYWORDS: Belgium, parliament, legislative careers, legislative turnover

\section{Inleiding}

Sinds de Franse Revolutie hoort de politieke macht te liggen bij door het volk verkozen mandatarissen. In tegenstelling tot het ancien régime moet de politieke elite in een parlementair systeem zich legitimeren via een regelmatige confrontatie met de kiezer. Het parlementair systeem is sinds de 19de eeuw bovendien gedemocra- 
tiseerd door de uitbreiding van het stemrecht. De democratisering van de politiek is niet alleen het verhaal van sociale contestatie en politieke omwentelingen. Op langere termijn heeft die ook geleid tot een ingrijpende mutatie van de parlementaire elite. Politiek-wetenschappelijk en historisch onderzoek naar de longitudinale verschuivingen in het profiel van de volksvertegenwoordiging - zowel qua parlementaire circulatie als qua sociografische evoluties - kan intussen bogen op een waaier aan landenstudies en aan publicaties die een transnationaal comparatief perspectief bieden. Tot dusver is de Belgische casus daarbij grotendeels achterwege gebleven. Hoewel de periode na 1945 reeds in kaart is gebracht (Fiers, 2000) moet de 'collectieve biografie' van de Belgische parlementaire elite nog geschreven worden.

Deze lacune is te betreuren. Enerzijds omdat het Belgische parlementaire regime sinds 1830 een haast ononderbroken continuïteit vertoont, in tegenstelling tot frequente regimewissels in buurlanden als Frankrijk of Duitsland. Anderzijds omdat men terug moet gaan tot de 19de eeuw om het effect van, bijvoorbeeld, de doorbraak van de massademocratie en gestructureerde politieke partijen op de volksvertegenwoordiging te kunnen nagaan. Dit artikel wil daarbij een eerste aanzet leveren, met betrekking tot de circulatie van parlementsleden sinds het ontstaan van België. Aan de hand van een zelf opgestelde dataset van alle Belgische parlementsleden sinds 1830, kan de circulatie van de Belgische kamerleden sinds 1831 in kaart gebracht worden. Deze dataset, afgesloten op 21 januari 2008, vormt de bron voor alle grafieken en tabellen die in het artikel aan bod komen. Door deze dataset kan de parlementaire circulatie vanuit drie invalshoeken benaderd worden: gemiddelde parlementaire ervaring, vernieuwingsgraad bij verkiezingen en spreiding van kamerleden naar gelang van de duur van het mandaat. De Belgische casus kan dan geconfronteerd worden met de onderzoekshypotheses en -resultaten die uit het buitenlands onderzoek naar voor geschoven werden. Het empirische luik blijft beperkt tot de Kamer van volksvertegenwoordigers, waar sinds de aanvang van het Belgische tweekamerstelsel het politieke zwaartepunt ligt (Stengers, 1990). Er zal evenmin ingegaan worden op de sociografische dimensie. In een eerste luik (deel 2) volgt een beknopte beschrijving van de wetenschappelijke literatuur met betrekking tot de mogelijke determinanten van parlementaire circulatie. Na de presentatie van de Belgische data (deel 3) volgt de confrontatie met eerdere onderzoeksresultaten uit andere landen (deel 4). 
PARLEMENTAIRE CIRCULATIE BELGISCHE KAMER VAN VOLKSVERTEGENWOORDIGERS, 1831-2008

\section{Onderzoek naar parlementaire circulatie: een beknopt overzicht}

De wetenschappelijke literatuur over de circulatie van parlementsleden vertrekt vanuit diverse perspectieven. Er is een stroming die zich focust op de determinanten en de internationale vergelijking van de vernieuwingsgraad bij verkiezingen, de zogenaamde turnover. De wetenschappelijke aandacht voor de parlementaire turnover kreeg een stimulans door kritiek op de vele zittende Amerikaanse parlementsleden die zonder problemen herkozen worden. Het overwicht van deze 'veilige' zetels zou leiden tot beleidsinertie en tot een democratisch deficit (Somit, Wildenmann, Boll \& Römmele, 1994, pp. 30-31). Parlementaire circulatie komt daarnaast (vaak zijdelings) aan bod als een deelaspect in het onderzoek naar parlementaire elites. De studies van Best en Cotta (Best \& Cotta, 2000; Cotta \& Best, 2007) naar het profiel van de Europese parlementaire elite sinds 1848 zijn daarbij de referentiewerken. Vooral hun eerste werk behandelt parlementaire circulatie, bij de verklaring voor de verschillen in trajecten die de Europese landen hebben afgelegd naar de democratisering van hun politiek systeem. De circulatie bepaalt uiteraard mee de snelheid waarmee het politiek personeel zich kan vernieuwen. Naast deze studies - die meerdere Europese landen bestrijken - zijn er publicaties die zich richten op een specifiek land, regime of tijdsgewricht. Veranderingen in circulatie en parlementaire ervaring worden daarbij gerelateerd aan de effecten van de professionalisering en democratisering van het parlementaire ambt in de 19de en 20ste eeuw (Van Den Berg, 1983; Walkland, 1979; Rush, 2004; Dogan, 2003). En het werk van Nelson Polsby over de institutionalisering van het Amerikaanse Huis van Afgevaardigden (1968) heeft ertoe geleid dat de circulatie onder parlementsleden als graadmeter voor parlementaire institutionalisering gebruikt wordt, zij het dat deze laatste onderzoeksstroming niet onomstreden is (Hibbing, 1999).

Verklarende variabelen die uit deze werken naar voor komen zijn te herleiden tot twee grote structurele verklaringen: institutionele omgevingsfactoren en de rol van politieke partijen als selectiekanaal voor politiek personeel. De institutionele factoren zijn het kiessysteem en - specifiek voor de werken die een perspectief op langere termijn hanteren - de uitbreiding van het stemrecht. Het kiessysteem blijkt de belangrijkste verklaring bij de internationale variatie van de hedendaagse parlementaire turnover. Politieke systemen met evenredige vertegenwoordiging kennen in de regel een grotere parlementaire vernieuwing bij verkiezingen dan landen met een meerderheidssysteem (Matland \& Studlar, 2004). Ook in de werken die zich richten op de historische variatie in circulatie, bijvoorbeeld Cotta en Best (2007) en Van Den Berg (1983), vormen wijzigingen in het kiessysteem breukmomenten. Net als de omvang van het electoraat is het kiessysteem mee bepalend voor de electorale machtsverhoudingen. 
Maar het kiessysteem is ook nog om een andere reden relevant, het bepaalt namelijk voor een stuk de verhoudingen tussen de individuele volksvertegenwoordiger en zijn politieke partij. Zeker in West-Europa vormen politieke partijen sinds de democratisering van het stemrecht een cruciale schakel tussen electoraat en parlement. De kiezer wordt er geconfronteerd met door partijen geselecteerde kandidaten (Norris, 1997). Matland en Studlar (2004) linken de lagere circulatie bij meerderheidssystemen aan het feit dat parlementsleden er een groter persoonlijk aandeel in hun herverkiezing hebben en partijen dus minder geneigd zullen zijn om zittende parlementsleden niet meer te selecteren. De hypothese over een decline of parliament veronderstelt juist dat partijen steeds meer greep krijgen op de kandidatenselectie. Het individuele parlementslid boet zo aan zelfstandigheid en macht in (Depauw, 2002). De ontwikkeling van de partijorganisatie, van 19deeeuwse kiesvereniging naar de hedendaagse permanente structuren, is dan ook de tweede verklaring die telkens opduikt. Somit benadrukt dat de verklaring steeds een combinatie van institutionele en partijgebonden factoren moet omvatten. De hoge kans op herverkiezing van Amerikaanse parlementsleden laat zich enkel verklaren door een combinatie van een meerderheidssysteem én een selectiesysteem via primaries. Canada, waar nochtans een vergelijkbaar kiessysteem bestaat, kent immers een veel hogere vernieuwing bij verkiezingen (Somit et al., 1994, p. 14).

Cotta en Best (2007) leggen, bij de impact van partijstructuur op het profiel van de parlementaire elite, sterk de nadruk op de opkomst van organized mass parties. Het concept 'massapartij' impliceert dat partijkandidaten en -verkozenen ondergeschikt zijn aan de partijorganisatie. Dit in tegenstelling tot de oudere kaderpartij (Duverger, 1951). Voor Cotta en Best (2007, pp. 437 \& 452-456) vormt de doorbraak van de socialisten - die het model van de massapartij initiëren - rond het einde van de 19de eeuw de belangrijkste partijpolitieke verklaring voor het veranderende profiel van de parlementaire elite. De opkomst van de socialisten vormt als het ware een pendant van de democratisering van het stemrecht. Best en Cotta antwoorden echter niet expliciet of dit ook een zichtbaar effect genereert op de parlementaire circulatie. Matland en Studlar (2004, pp. 98-99 \& 105) ontkennen in ieder geval dat het ideologische onderscheid tussen links en rechts zich aan het eind van de twintigste eeuw nog vertaalt in verschillende circulatiepatronen. Dit hoewel linkse partijen geassocieerd worden met een groter wantrouwen tegen lang zetelende mandatarissen.

Er is nog een verklaring, één die zich echter moeilijk laat klasseren. Nelson Polsby interpreteerde de trendmatig dalende Amerikaanse turnover sinds het begin van de negentiende eeuw als het gevolg van de institutionalisering van het Amerikaanse Huis van Afgevaardigden. Institutionalisering duidt dan op een evolutie naar interne complexiteit en een groeiend onderscheid met de externe omgeving. Polsby 
zag de dalende turnover als een toenemende geslotenheid van de parlementaire instelling (1968). Ieder parlementair systeem met een zekere continuïteit zou dan moeten tenderen naar een lagere turnover. Deze hypothese is moeilijk vol te houden. Zo levert een vergelijking van de parlementaire circulatie in de Franse Derde Republiek en het Amerikaanse Huis van Afgevaardigden tussen 1870 en 1940 geen grote verschillen op (Graham, 1982). Dit spreekt Polsby’s hypothese tegen, want het Huis heeft dan al een stabiele geschiedenis achter zich, terwijl de Derde Republiek een wankel en omstreden politiek regime is. John Hibbing waarschuwt dan ook dat het Amerikaanse politieke systeem - met partijen die geen directe greep hebben op de selectie van hun kandidaten - te specifiek is. Hibbing ziet de parlementaire circulatie in een Europese context eerder als een indicatie voor de institutionalisering van politieke partijen. Een hoge afwisseling van het politiek personeel lijkt hem een teken dat partijen minder afhankelijk worden van de merites van individuele politici (Hibbing, 1999, p. 158).

Polsby's hypothese mag evenwel niet helemaal afgeschreven worden. Het werk van Best en Cotta (2000, p. 512) leert namelijk dat regimebreuken - met de bijhorende politieke instabiliteit - telkens een zichtbaar effect hebben op de parlementaire circulatie. Het begin van een nieuw parlementair regime vertoont een hoge circulatie, om geleidelijk plaats te maken voor meer stabiliteit, eens het regime vast in het zadel zit. Op Europees vlak is de trend naar democratisering van het politieke bestel sinds 1848 meermaals afgeremd en het parlementaire regime kwam soms zelfs helemaal te verdwijnen: de laatste restauratiepogingen van het ancien régime, fascistisch Italië, nazi-Duitsland enzovoort. België is hieraan sinds 1830 grotendeels ontsnapt, behalve tijdens de beide Duitse bezettingen tijdens de Wereldoorlogen. Beide bezettingen vormen de enige voorbeelden waarbij het parlementaire leven in België abrupt en voor langere tijd werd stilgelegd.

Nog een woord over de empirische bevindingen uit het buitenlandse onderzoek. Best en Cotta (2000) zien in de modernisering van het parlementaire bestel naar een massademocratie met georganiseerde politieke partijen twee centrale evoluties: democratisering en professionalisering van de parlementaire elite. Michael Rush (2004, pp. 131-138) koppelt voor Groot-Brittannië die professionalisering aan een ander type parlementaire carrière. De evolutie naar politici die zich voltijds met hun verkozen mandaat bezighouden en er financieel afhankelijk van zijn, heeft er na 1868, de eerste democratisering van het stemrecht, geleid tot langere parlementaire carrières, een lagere circulatie en een gemiddelde veroudering van de parlementaire elite. Democratisering en professionalisering lijken echter moeilijk te verzoenen. Het ene begrip duidt op een bredere toegang tot het parlement, terwijl het andere van parlementsleden een aparte beroepsklasse maakt, met eigen standaarden en netwerken, waarover de buitenwereld niet beschikt (Best \& Cotta, 2000, p. 495). 
Dogan (2003) toont hoe democratisering en professionalisering toch naast elkaar functioneren. De carrièreduur onder Franse parlementsleden van de Derde Republiek vertoont een grote scheeftrekking. Dogan onderscheidt enerzijds een kleine kern onder de parlementaire elite met lange, stabiele carrières, die soms vijf legislaturen of meer zetelden (6\% van de parlementsleden tussen 1870 en 1940). Anderzijds verdwijnt zo’n $47 \%$ van de verkozenen al na één mandaat. Een louter gemiddelde kan dus evenveel verhullen als verduidelijken... Op internationale schaal bevestigt het onderzoek van Best en Cotta (2000, pp. 505 \& 512) deze tendens: over de lange termijn - sinds 1848 - ligt de vernieuwing van de parlementsleden bij verkiezingen op ongeveer $30 \%$, terwijl de parlementsleden gemiddeld drie of meer termijnen zetelen. Dus hoewel het parlement zich bestendig vernieuwt, kennen parlementaire carrières een zekere stabiliteit.

Naast de evoluties op langere termijn zorgen regimeveranderingen of aanpassingen aan stemrecht en kiessysteem voor omwentelingen van de circulatiecijfers. Het onderzoek naar de turnover gedurende de laatste decennia in geïndustrialiseerde landen komt tot de volgende spreiding: in de Verenigde Staten wordt gemiddeld $84 \%$ van de parlementsleden herkozen, terwijl dat in het andere uiterste Canada zo'n $53 \%$ bedraagt (Matland \& Studlar, p. 93). Zoals reeds aangehaald, blijkt het verschil in kiessysteem een groot deel van de hedendaagse variatie in circulatie te verklaren, maar Matland en Studlar bevestigen ook het effect van de parlementaire institutionalisering. Landen - zoals Portugal - met een relatief jonge democratische en parlementaire traditie vertonen een grotere turnover.

\section{Parlementaire ervaring en circulatie onder de Belgische volksvertegenwoordigers (1831-2008)}

Een belangrijke graadmeter voor de carrière van het Belgische parlementslid is de parlementaire ervaring. Grafiek 1 toont de gemiddelde parlementaire ervaring van Belgische kamerleden na iedere vernieuwing van de Kamer van volksvertegenwoordigers. Er wordt enkel rekening gehouden met de parlementaire ervaring in de Kamer. Dit leidt tot een zekere onderschatting, maar maakt de berekeningen een stuk eenvoudiger. Tot de hervorming van het tweekamerstelsel in 1993/95 is het gebruikelijker om van Kamer naar Senaat over te stappen dan andersom. Tot dan geldt immers een hogere leeftijdsgrens voor de Senaat dan voor de Kamer (Fiers, 2000, p. 33). Tussen 1831 en 1995 zijn er dan ook slechts 168 kamerleden (op 2318, of ongeveer 7\%) die een kamermandaat opnemen ná een senaatsmandaat. 


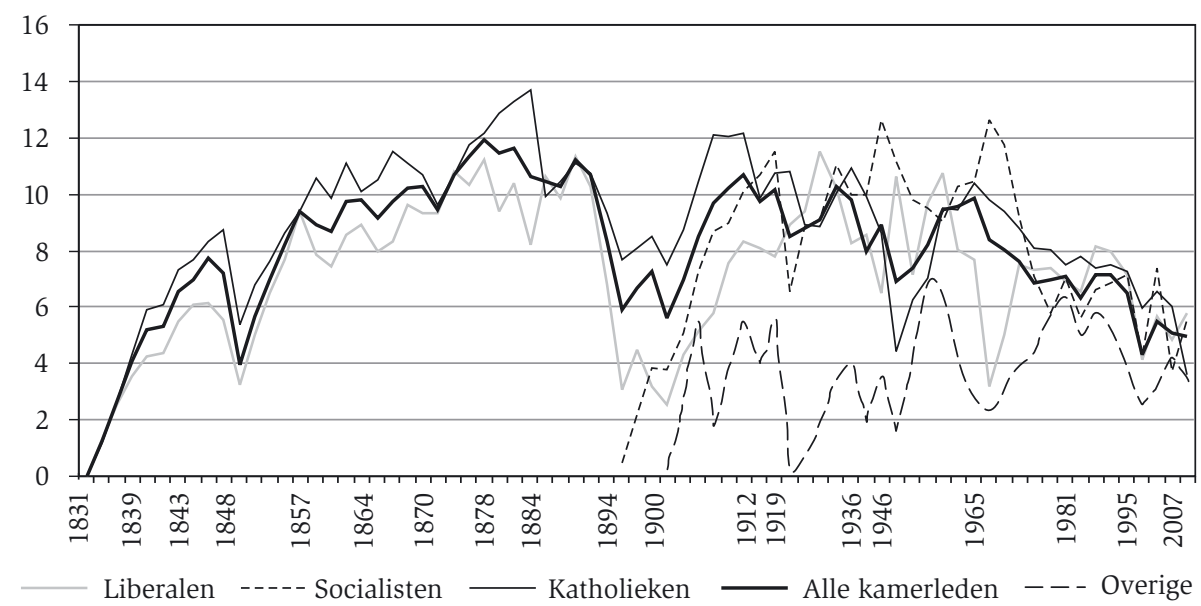

GRAFIEK 1. De gemiddelde ervaring in de Kamer (in jaren) na verkiezingen, 1831 tot 2007.'

Tot het einde van de negentiende eeuw vertoont de grafiek een relatief eenduidig patroon: het algemene gemiddelde groeit stelselmatig aan, tot meer dan tien jaar. Na 1882 piekt het gemiddelde onder de katholieke kamerleden op bijna 14 jaar. Enkel de verkiezingen van 1848 markeren een scherpe tijdelijke daling. Het algemeen patroon van de eerste zestig jaar parlementaire geschiedenis is er dus een van langer wordende en stabiele carrières. Hibbings kritiek op Polsby in gedachten, hoeft dit niets te zeggen over de institutionalisering van de Kamer van volksvertegenwoordigers, maar er vormt zich in deze periode duidelijk een parlementaire elite.

Na 1894 volgt er een drastische omslag van het patroon. Het liberale gemiddelde haalt amper nog vier jaar. De katholieke lijn vertoont een minder uitgesproken daling. Tegelijk slagen de socialisten er als derde politieke stroming in om kamerzetels te halen. Na 1900 corrigeert de toestand zich opnieuw. Vlak voor de Eerste Wereldoorlog zetelen de kamerleden opnieuw gemiddeld ongeveer 10 jaar. De negentiende-eeuwse stabiliteit zien we na 1918 niet meer opduiken. De 'traditionele' Belgische politieke partijen krijgen vanaf het interbellum af te rekenen met toenemende concurrentie. De Frontpartij breekt door in 1919, (tijdelijke) rexistische en communistische successen volgen in 1936 en 1946 . Het succes van deze nieuwe formaties hoeft de gemiddelde ervaring onder de traditionele partijen echter niet automatisch te doen dalen. Het electorale verlies zou zich kunnen beperken tot de nieuwkomers, terwijl de gevestigde waarden - dankzij een gunstiger positie op de kieslijst - standhouden. Van den Berg (1983, p. 211) bevestigt dit ook voor Nederland: electorale achteruitgang werkt de vergrijzing van een partij in de hand. 
De tendens onder de klassieke partijen vertoont na de Eerste Wereldoorlog grotere schommelingen. Het gemiddelde van de CVP-PSC-kamerleden uit 1946 benadert bijna dat van 1848, terwijl dat van de socialisten dan het dubbele bedraagt. Ook in 1965 liggen de traditionele partijen ver uiteen.

In 1965 wordt dan een dalende tendens ingezet, die eigenlijk tot op vandaag aanhoudt. Vanaf het einde van de jaren '60 zien we voor de drie traditionele politieke families (de unitaire partijen splitsen tussen 1968 en 1978) een uitgesproken daling van de parlementaire ervaring in de Kamer van volksvertegenwoordigers. Grote verschillen tussen de partijfamilies blijven daarbij uit. De verkiezingen van 1995 springen eruit, met een algemeen gemiddelde dat een scherpe knik naar beneden neemt. Maar de daling van de parlementaire ervaring lijkt zich na 1995 nog verder te manifesteren. De gemiddelde ervaring van de kamerleden is dan op een niveau beland dat dit van de beginjaren van de Belgische parlementaire geschiedenis benadert.

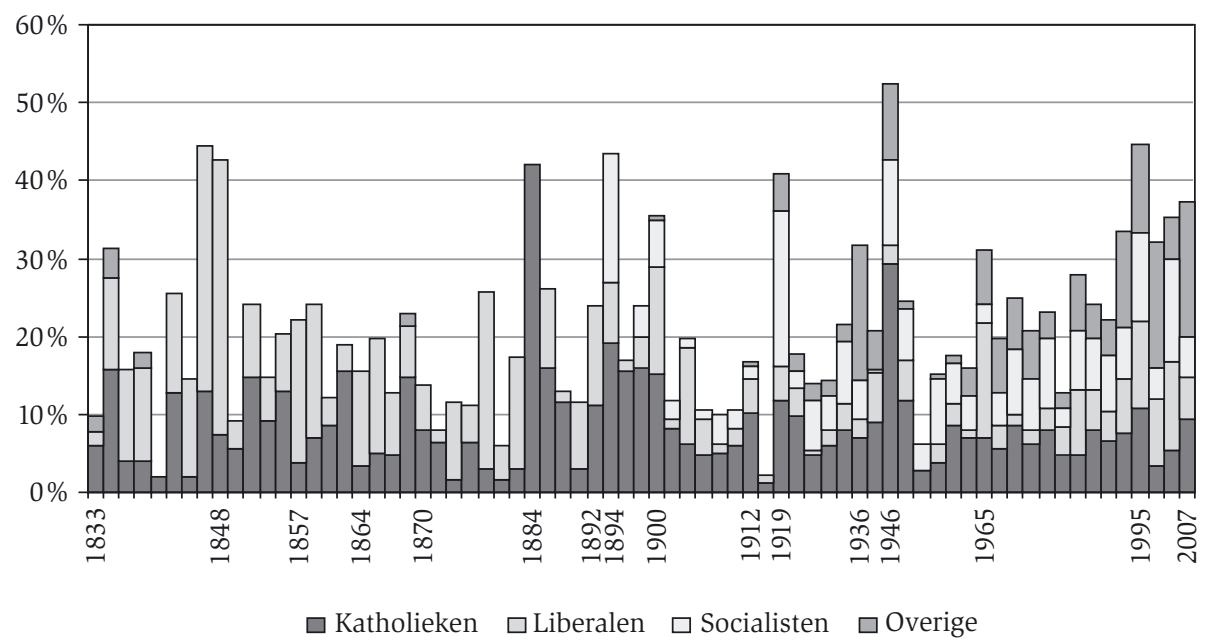

GRAFIEK 2. De procentuele vernieuwing van de volksvertegenwoordigers na verkiezingen, uitgesplitst per partijfamilie (enkel de absolute nieuwkomers), 1833-2007.

De turnover, of de vernieuwingsgraad bij verkiezingen, belicht de parlementaire circulatie vanuit een andere invalshoek. Grafiek 2 toont de mate waarin de Kamer zich vernieuwt vanaf de eerste legislatuur (1831-1833). Per verkiezingsjaar wordt weergegeven hoeveel absolute nieuwkomers de verkiezingen hebben opgeleverd, als een percentage van het aantal kamerzetels dat vernieuwd werd. Voor de interpretatie van deze grafiek moet immers rekening gehouden worden met het bestaan 
van partiële verkiezingen. Tot de grondwetswijziging van 1921 ging bij (tweejaarlijkse) verkiezingen slechts de helft van de provincies naar de stembus. Slechts in tien gevallen (1833, 1848, 1857, 1864, 1870, 1892, 1894, 1900, 1912 en 1919) worden tussen 1831 en 1921 alle kamerleden tegelijk aan een herverkiezing onderworpen. Een substantieel onderscheid tussen partiële en algemene verkiezing blijkt niet uit de grafiek. De vernieuwing in 1848, 1894 en 1900 vertoont weliswaar pieken, maar partiële verkiezingen in 1847 en 1884 halen een gelijkaardige turnover.

De hoge turnover in 1848, 1894 en 1900 sluit aan bij de cijfers over de gemiddelde parlementaire ervaring. Ook de vernieuwing bij de verkiezingen van 1847 en 1884 is op de eerste grafiek merkbaar, bij de partijgemiddelden. In 1847 boeken de liberalen een aanzienlijke zetelwinst. Dat brengt een pak liberale nieuwkomers en een dalend liberaal gemiddelde met zich mee. De katholieke nederlaag belemmert katholieke nieuwkomers en de gemiddelde ervaring van de resterende katholieken stijgt. In 1884 doet zich het omgekeerde scenario voor. Ook de eerste naoorlogse verkiezingen blijken telkens een katalysator voor een hoge turnover te zijn. In 1919 valt daarbij het socialistische aandeel op, in 1946 dat van de katholieken. Verder merken we na de Eerste Wereldoorlog nog een sterke partijgebonden vernieuwing in 1936 bij de niet-traditionele partijen en in 1965 bij de liberalen. Vanaf 1991 is een hoge vernieuwing via de niet-traditionele formaties eigenlijk een continu gegeven.

In tegenstelling tot de eerste grafiek is een longitudinale trend moeilijker te onderscheiden in de tijdsreeks. Toch is er in grote lijnen een onderscheid aan te brengen tussen de 19de en de 20ste eeuw. Tot de Eerste Wereldoorlog evolueert de totale turnover op langere termijn naar ongeveer $10 \%$. Het interbellum vertoont vooral fluctuatie maar na 1945 zet er zich een duidelijke stijgende tendens in, naar meer dan 20\% turnover vanaf 1965 en zelfs meer dan 30\% in de jaren '90. Enkel 1950 en 1978 vormen een uitzondering, in beide gevallen heeft de legislatuur slechts een jaar geduurd. In 1950 gaan de meeste partijen opnieuw met de kandidaten van het vorige jaar naar de kiezer (Van Braband, 2003). Waarschijnlijk gebeurt hetzelfde in 1978. Wanneer de Belgische vernieuwingsgraad sinds 1831 vergeleken wordt met buitenlandse resultaten, dan levert een kamerzetel een relatief stabiel mandaat op. De gemiddelde turnover bij Best en Cotta (2000, p. 504) van zeven Europese landen sinds 1848 schommelt immers tussen 30 en $60 \%$.

Naast de gemiddelde ervaring en de electorale turnover vormt de spreiding van de kamerleden volgens de duur van hun mandaat een derde invalshoek. Een stabiele gemiddelde ervaring kan immers een scheeftrekking onder de kamerleden maskeren wanneer de turnover vooral de onervaren mandatarissen treft. Het overwicht van korte carrières is minder uitgesproken dan de resultaten van Dogan (2003) 
voor de Franse Derde Republiek, behalve in de periode sinds 1965. Nagenoeg de helft van alle kamerleden die sinds de verkiezingen van 1965 een kamermandaat aanvatten, zetelde minder dan vijf jaar. In dezelfde periode is er ook een merkbare daling van het aandeel mandaten van vijftien jaar en langer. Het aandeel van de mandaten tussen vijf en vijftien jaar is sinds 1831 evenwel stabiel gebleven. Die stabiliteit corrigeert het beeld van de stijgende turnover en de dalende gemiddelde ervaring in diezelfde tijdsspanne. Een hoge circulatie en professionele politici met langere carrières sluiten elkaar niet uit. De periode met het grootste aandeel langere carrières (vijftien jaar en meer) is merkwaardig genoeg die tussen 1894 en 1919. Dit is uitgerekend het ogenblik waarop de parlementaire ervaring en de electorale turnover aan grote schommelingen onderhevig zijn.

TABEL 1. De spreiding van de kamerleden volgens duur van het mandaat, absolute aantallen en procenten, 1831-2008.

\begin{tabular}{|c|c|c|c|c|c|c|c|c|c|c|c|}
\hline & \multicolumn{2}{|c|}{$<5 \mathrm{j}}$. & \multicolumn{2}{|c|}{ 5-14 j. } & \multicolumn{2}{|c|}{$15-24 j}$. & \multicolumn{2}{|c|}{$25-34 \mathrm{j}}$. & \multicolumn{2}{|c|}{$>34 \mathrm{j}}$. & \multirow{2}{*}{$\begin{array}{l}\text { Totaal } \\
\text { Abs }\end{array}$} \\
\hline & Abs & $\%$ & Abs & $\%$ & Abs & $\%$ & Abs & $\%$ & Abs & $\%$ & \\
\hline $1831-1848$ & 93 & 36,76 & 98 & 38,74 & 36 & 14,23 & 17 & 6,72 & 9 & 3,56 & 253 \\
\hline $1848-1894$ & 145 & 30,59 & 187 & 39,45 & 80 & 16,88 & 44 & 9,28 & 18 & 3,80 & 474 \\
\hline 1894-1919 & 69 & 22,04 & 115 & 36,74 & 85 & 27,16 & 26 & 8,31 & 18 & 5,75 & 313 \\
\hline $1919-1965$ & 223 & 29,81 & 275 & 36,76 & 169 & 22,59 & 67 & 8,96 & 14 & 1,87 & 748 \\
\hline $1965-2008$ & 469 & 49,47 & 365 & 38,50 & 101 & 10,65 & 12 & 1,27 & 1 & 0,11 & 948 \\
\hline $1831-2008$ & 999 & 36,51 & 1.040 & 38,01 & 471 & 17,21 & 166 & 6,07 & 60 & 2,19 & 2.736 \\
\hline
\end{tabular}

\section{Verklarende factoren voor het veranderende circulatiepatroon onder de Kamerleden}

\subsection{Institutionele factoren}

De institutionele omgeving waarbinnen het Belgische parlementaire leven zich afspeelt vertoont sinds 1831 een grote stabiliteit. Er zijn twee cruciale keerpunten aan te duiden. In 1894/1900 herziet de wetgever zowel het stemrecht als het kiessysteem en met de verkiezingen van 1995 wordt het Belgische tweekamerstelsel aangepast aan de gevorderde federalisering van het land. Daarnaast heeft ook de knik in de parlementaire ervaring in 1848 een institutionele verklaring. Als reactie op de Europese revolutiegolf laat de liberale regering in dat jaar een verbod stemmen om nog als ambtenaar in Kamer of Senaat te zetelen. Deze réforme parlemen- 
taire moet het de regering voortaan onmogelijk maken om via haar ambtenaren het parlement tot volgzaamheid te dwingen (Witte, 1981). De parlementaire carrière van een aanzienlijke fractie van de kamerleden kent door de onverenigbaarheid een voortijdig einde. Het einde van het 'ambtenarenparlement' heeft echter slechts een tijdelijk effect op de parlementaire circulatie. De gemiddelde ervaring neemt naderhand weer toe en knoopt zo aan met de trend van voor 1848.

Onder druk van de arbeidersbeweging wordt het elitaire cijnskiesrecht in 1893 vervangen door het algemeen meervoudig stemrecht: een stem voor iedere volwassen man, eventueel aangevuld met één tot twee bijkomende stemmen naar gelang van het diploma of de eigendom. De electorale basis van de parlementaire representatie vertienvoudigt in één klap. Een eerste gevolg is de parlementaire doorbraak van de socialisten. De Belgische Werkliedenpartij (BWP) haalt in 1894 meteen 28 zetels. De liberale partij moet het onderspit delven; ook gevestigde waarden als Walthère Frère-Orban en Jules Bara verdwijnen uit de Kamer. Enkel de radicale liberalen houden zich nog wat staande, dankzij kartels met de BWP. Een nieuw partijsysteem, waarin de BWP op termijn de plaats van de liberalen inneemt, zou het logische gevolg zijn. Maar in 1899 wordt het kiessysteem volledig omgegooid. Het meerderheidsstelsel wordt vervangen door de evenredige vertegenwoordiging, een Europese primeur. De hervorming moet het electorale overleven van de liberale partij mogelijk maken, als een buffer tegen de socialisten (Stengers, 2000). De discrepantie tussen het liberale stemmen- en zetelaantal verdwijnt en de liberalen kunnen in 1900 de neerwaartse trend ombuigen.

Het effect van deze institutionele hervormingen ebt snel weg, net zoals na 1848 . Tegen de verwachtingen in, want uit het onderzoek van Matland en Studlar (2004) blijkt het kiessysteem sterk bepalend te zijn voor de parlementaire turnover. De gemiddelde ervaring, net als de turnover, sluit tussen 1900 en 1914 weer aan met de 19de-eeuwse trend. De kennelijk beperkte impact van de uitbreiding van het stemrecht en de evenredige vertegenwoordiging is niet vanzelfsprekend. De massademocratie maakt de politieke partij tot het aangewezen kanaal voor parlementaire representatie. De evenredige vertegenwoordiging uit 1899 past de consequenties van deze nieuwe logica toe. In plaats van de individuele kandidaat komt de politieke partij centraal te staan. Zetels worden voortaan toegewezen aan kieslijsten en de volgorde op de kieslijst wordt doorslaggevend voor de zetelverdeling onder de kandidaten. De relatieve sterkte van de partijen wordt tussen twee verkiezingen gewaarborgd door het invoeren van parlementaire opvolgers, zodat partijen hun zetels kunnen behouden wanneer een parlementslid overlijdt of opstapt (Weber, 2003, p. 318). De wetgever van 1899 maakt het kandidaten de facto haast onmogelijk om nog buiten partijverband een parlementair mandaat te veroveren. Er volgt echter geen direct effect op de parlementaire circulatie. 
De krachtlijnen van de evenredige vertegenwoordiging uit 1899 blijven tot op vandaag in voege. Het stemrecht kent na 1893 nog drie aanpassingen. In 1919 verdwijnt het meervoudige stemrecht, iedere volwassen man krijgt voortaan één stem. Vrouwen moeten wachten tot 1948 en de leeftijdsgrens wordt in 1981 van 21 op 18 jaar gebracht. In 1919 leidt dat tot een aanzienlijke toename van nieuwe socialistische kamerleden. De BWP maakt door de democratisering van het mannenstemrecht een tweede sprong en komt bijna op gelijke hoogte met de katholieken. De wijzigingen qua stemrecht en kiessysteem lijken dus vooral effect te sorteren op de machtsverschuivingen onder de partijen, eerder dan voor een andere carrièreduur of circulatie te zorgen.

De institutionele context van de Kamer van volksvertegenwoordigers kent een grondige wijziging na de verkiezingen van 1995, na een nieuwe ronde in de staatshervorming. De grondwetswijziging van 1993 hertekent het Belgische parlementaire regime in federale zin. Kamer en Senaat krijgen een rechtstreeks verkozen Vlaams en Waals parlement naast zich. De omvorming van de unitaire tot een multilevel staatsstructuur - ingezet met een rechtstreeks verkozen Europees (1979) en Brussels (1989) parlement - is daarmee een feit. Daarnaast wordt het tweekamerstelsel uit 1831 herzien. De Senaat wordt omgevormd tot een reflectiekamer en het politieke zwaartepunt komt exclusief bij de Kamer te liggen. Ter compensatie van de nieuwe deelstaatparlementen worden Kamer en Senaat afgeslankt. Het aantal kamerleden daalt in 1995 van 212 naar 150. Ten slotte beoogt de hervorming van 1993 het dualisme tussen regering en parlement te versterken. Zo kan de regering het parlement niet langer naar goeddunken ontbinden en verkiezingen uitschrijven. Bovendien mag een minister sinds 1995 niet tegelijk parlementslid blijven, een opvolger vervangt hem of haar voor de duur van het regeringsmandaat. $\mathrm{Al}$ in de jaren ' 80 circuleren voorstellen om een onverenigbaarheid in te voeren tussen een parlementair en een ministerieel mandaat, teneinde de positie van het parlement en het dualisme tussen parlement en regering te versterken. Sinds de herziening van 1993 is dit principe in de grondwet opgenomen (Leus \& Veny, 1996, pp. 238242). Het systeem is sindsdien ook overgenomen door de deelstaten. Sinds 1995 gaat het om 50-tal regeringsleden die in de diverse parlementen vervangen moeten worden. Dit betekent een vertekening van de feitelijke gemiddelde parlementaire ervaring: voor de duur van hun ministercarrière verdwijnen deze verkozenen uit de statistieken.

Het effect van de grondwetswijziging is onmiddellijk zichtbaar. Een deel van de uittredende kamerleden opteert in 1995 om over te stappen naar het regionale niveau. Ondanks de daling van de kamerzetels komt er zo veel ruimte voor vernieuwing. De turnover bedraagt dat jaar meer dan $40 \%$, maar ook de parlementaire ervaring kent een sterke daling. De instroom van nieuwe leden wordt met andere 
woorden niet gecompenseerd door de stijgende ervaring van de blijvers. Diverse politieke tenoren verdwijnen als minister immers uit de Kamer of ze stappen over naar de Senaat. De Senaat is weliswaar afgeslankt tot een reflectiekamer, maar de kieskring voor senatoren is veel ruimer dan deze voor kamerleden. De politieke sterkhouders hopen zich zo te plebisciteren. De hervormingen van 1995 zorgen op termijn niet voor een trendbreuk, evenmin als na 1894/1900. De daling van de gemiddelde ervaring en de hoge turnover zetten zich verder.

\subsection{De impact van de politieke partijen}

In de regel komt men zonder partijsteun niet in het parlement. De representatieve functie van het parlement verloopt in een gedemocratiseerd politiek systeem via politieke partijen. Een partij rekruteert en selecteert kandidaten die ze onder haar vlag aan de kiezers presenteert. De Belgische wetgever onderschrijft dit principe sinds 1877, met de invoering van de voorgedrukte kiesbrieven met partijkleuren. Sinds 1899 verdeelt het kiessysteem de zetels in eerste instantie onder de kieslijsten. Tot 2000 beschikt de kiezer bovendien slechts over een kleine speelruimte om de kandidatenvolgorde via een voorkeurstem nog te wijzigen (Dewachter, 2001, p. 375; Pilet, 2007, pp. 175-176). Het is deze volgorde die uitmaakt welke kandidaten een mandaat behalen. De lijstvorming binnen de politieke partij is naast het verkiezingsresultaat dus de cruciale factor voor de herverkiezing. Controleren de parlementsleden zelf de selectie en de lijstvolgorde, dan staat enkel een verkiezingsnederlaag of een vrijwillig afscheid een nieuw mandaat nog in de weg. Het tegendeel - lijstvorming via partijleden of partijleiding - opent perspectieven om het politieke personeel vlotter te vernieuwen.

Best en Cotta (2007) nemen de doorbraak van de massapartij als maatstaf voor het gewicht van georganiseerde partijen op de parlementaire representatie. Ze gaan er vanuit dat met dit partijtype de wijze van kandidatenselectie zal veranderen. In de loop van de twintigste eeuw evolueert niet alleen de partijstructuur maar ook de electorale context waarbinnen de partijen opereren wijzigt. Verkiezingsresultaten volgen steeds vaker een nationale trend. Nationale thema's en boegbeelden gaan zwaarder doorwegen dan lokale factoren (Caramani, 2004). Partijen zullen daar bij hun kandidatenselectie rekening mee houden. Het relatieve belang van een regionale machtsbasis als garantie op herverkiezing brokkelt af. Men kan aannemen dat de parlementaire circulatie zal toenemen naarmate de massapartij doorbreekt en de verkiezingsresultaten nationaliseren.

De gemiddelde parlementaire ervaring onder de Belgische kamerleden lijkt de hypothese slechts deels te ondersteunen. De resultaten tot 1894/1900 lijken Best en 
Cotta gelijk te geven. Tussen het einde van het ambtenarenparlement (1848) en de intrede van de socialisten zorgen electorale verschuivingen tussen liberalen en katholieken voor louter tijdelijke pieken in de turnover; de gemiddelde ervaring blijft bovendien stabiel. De katholieke en liberale 'kaderpartijen' zijn feitelijk niet veel meer dan een losse bundeling van lokale kiesverenigingen, enkel actief in verkiezingstijd, en ze worden inderdaad gekenmerkt door een stabiele parlementaire elite. Zeker in landelijke gebieden zal een uittredend kamerlid zich moeiteloos opnieuw kandidaat kunnen stellen (Govaerts, 1997, p. 33). Zelfs in de grootsteden, waar de steun van een kiesvereniging onontbeerlijk is, geven de mandatarissen de toon aan in de lokale partijstructuur (Dechesne, 1974). Die toonaangevende positie van de parlementsleden is de hoeksteen bij Duvergers typering van de kaderpartij. De komst van de socialistische massapartij leidt in België echter niet tot een trendbreuk.

Tussen 1894 en 1914 vormt zich een stabiele socialistische parlementaire elite. Aan de vooravond van de Eerste Wereldoorlog is de gemiddelde parlementaire ervaring zelfs het hoogst onder de socialistische kamerleden. De scherpe daling van de gemiddelde ervaring onder socialisten in 1919 is enkel te wijten aan bijkomende kamerleden, na het afschaffen van het meervoudige stemrecht, zonder dat de vooroorlogse generatie moet plaatsruimen. Tot de jaren '60 zal de gemiddelde parlementaire ervaring onder socialisten hoog liggen, boven de tien jaar. Electorale klappen - zoals in 1939 en 1965 - treffen vooral de minder ervaren politici, want het zijn telkens jaren waarin de gemiddelde ervaring piekt, tot meer dan twaalf jaar. Naderhand volgt een structurele daling, maar ook hier is er geen wezenlijk verschil met de andere partijen. De hypothese van Best en Cotta, dat de doorbraak van de socialisten zal wegen op de parlementaire representatie, lijkt alvast voor de carrièreduur niet op te gaan.

In feite is er in de Belgische Werkliedenpartij geen breuk met het verleden inzake kandidatenselectie. De BWP onderscheidt zich door een complexe partijstructuur, waarin de parlementsleden als partijmandatarissen fungeren en zich moeten onderschikken aan partijbestuur en -congressen. Maar het opmaken van de kieslijsten blijft een zaak van de lokale federaties, die zeker tot na de Tweede Wereldoorlog angstvallig waken over hun lokale autonomie (Mommen, 1974). Enkel de aanduiding van gecoöpteerde senatoren is een zaak van de nationale partijleiding. De partij poogt wel te verhinderen dat de parlementsleden en petit comité zichzelf telkens opnieuw bovenaan de lijst zouden plaatsen: de BWP-statuten eisen een samenstelling van de kieslijst via een algemene ledenpoll. ${ }^{2}$ Hetzelfde gebeurt wanneer de katholieke partij zich in 1945 tot CVP omvormt en zich daarbij van een strakke partijstructuur voorziet. De CVP probeert via de ledenpoll lokale baronieën te vermijden maar ook hier moet de partijleiding ruimte laten aan de lokale par- 
tijfederaties (Debuyst, 1967). In de liberale partij blijft nog tot de stichting van de PVV in 1961 de traditie van de lokale autonomie sterk ingeburgerd.

Eind jaren '60 dient zich in de drie traditionele partijen echter een geleidelijke centralisering van de kandidatenselectie aan (Deschouwer, 1993, pp. 138-144). De verkiezingen van 1965 vormen daarbij het kritieke punt. De liberale partij heeft zichzelf intussen omgevormd tot de PVV en boekt een grote overwinning; haar zetelaantal gaat in een klap van 20 naar 48. In tegenstelling tot de oude liberale partij wil de PVV volop gelovigen voor zich winnen. Er moeten - tegen de lokale bezwaren in - zichtbare katholieke vernieuwers op de kieslijsten komen. Partijvoorzitter Vanaudenhove wil verhinderen dat de verruiming bij vage intenties blijft en trekt de lijstvorming naar zich toe. Hij slaagt daarin, omdat de verruiming electoraal lonend belooft te worden. ${ }^{3}$ Het voorbeeld van de PVV krijgt snel navolging. Onder de indruk van de electorale opdoffer wijzigt eind 1965 ook de CVP haar statuten, met onder meer een grotere greep van de partijleiding op de lijstvorming. ${ }^{4}$ In navolging van het maatschappelijke klimaat eind jaren '60, gesymboliseerd door de internationale studentenprotesten, forceren de partijen een verjonging van hun politiek personeel. Er worden binnen de partijen maximumleeftijden voor mandatarissen opgelegd, net als in Nederland (Dewachter, 1969; Ceuleers, 1974; Van den Berg, 1983, p. 205) Mede als gevolg van deze centralisering verdwijnt vanaf het einde van de jaren '60 de praktijk van de ledenpoll (De Winter, 1980). Er komen ook partijregels om het cumuleren van lokale en parlementaire mandaten in te perken (Dewachter, 1969, p. 85; Geldolf, 2006, p. 605). Dat laatste viseert de lokale machtsbasis van parlementsleden. De opgesomde hervormingen getuigen van de neiging om binnen de partijen een machtsconcentratie bij de parlementsleden te verhinderen. In de jaren '80 gaan de groene partijstatuten in naam van de ledeninspraak daarin het verst: ze leggen hun parlementsleden een maximumaantal termijnen op, het zogenaamde rotatieprincipe (Delwit \& De Waele, 1996, pp. 131-132).

Er zijn verschillende redenen voor deze ingrepen. Wellicht speelt in de geest van de jaren '60 een verlangen naar meer partijdemocratie mee, waarbij de partijleden zonder mandaten een grotere zeg krijgen. Tegelijk voltrekt zich een groeiende professionalisering van de partijen, die evolueren naar catch-all-partijen, die het volledige electoraat willen aanspreken (Best \& Cotta, 2007, p. 155). De levensbeschouwelijke tegenstelling tussen gelovigen en niet-gelovigen, het fundament van de Belgische verzuiling, verliest na het Tweede Vaticaans Concilie aan scherpte. Het profiel van de kandidaten wordt door de partijen bijgestuurd om op deze evolutie in te spelen. Dit veronderstelt dat de centrale partijstructuur kan ingrijpen in de plaatselijke lijstvorming. De PVV is daarbij een trendsetter door in 1965 katholieke kandidaten te presenteren. Een dergelijk verruimingsscenario is sindsdien wel vaker toegepast. Partijen hopen nieuwe electorale markten aan te boren en houden 
daar rekening mee bij de samenstelling van de kandidatenlijsten. De partijen mikken in de jaren '70 op verjonging en vervrouwelijking. In de jaren '80 hopen de Vlaamse socialisten gelovigen aan te trekken. En alle traditionele partijfamilies willen hun Vlaams of Waals profiel aanscherpen, om het electoraat van de regionalistische partijen aan te spreken.

De dalende ervaring van het parlementaire personeel vanaf de jaren '60 kan grotendeels toegeschreven worden aan de toenemende greep van de partijen op de kandidatenselectie. Tot dan volgt de gemiddelde ervaring grotendeels de hypothese van Van den Berg (1983, p. 211). Electorale stagnatie of neergang leidt tot een vergrijzing van de fractie. Dit is te zien bij de socialisten voor de Eerste Wereldoorlog: de electorale groei stagneert, maar de eerste generatie kamerleden uit 1894 weet zich te handhaven. De verkiezingsoverwinning van 1919 doet de gemiddelde leeftijd vervolgens dalen. Ook de electorale evolutie van de liberale partij kan afgelezen worden uit de gemiddelde ervaring. Nederlagen na de Eerste en Tweede Wereldoorlog leiden tot een stijging van het partijgemiddelde. Omgekeerd betekenen successen in 1939 en 1965 een scherpe daling. Dit patroon verandert na 1965. De drie traditionele partijfamilies moeten weliswaar continu terrein prijsgeven aan nieuwe politieke formaties, de drie traditionele partijfamilies zijn in 1961 goed voor 95\% van de kamerzetels, in 1995 nog voor zo’n 70\% (Deschouwer, 1999, p. 95). Maar ook hun gemiddelde parlementaire ervaring neemt ditmaal af. Die daling komt ditmaal niet louter door bijkomende kamerleden na verkiezingswinst, ook de meer ervaren politici moeten plaatsruimen. Hier speelt het effect van de door de partijen opgelegde leeftijdsgrenzen.

De centralisering van de lijstensamenstelling plaatst de parlementsleden in een zwakkere positie ten opzichte van de partijleiding (Hazan \& Rahat, 2006). Grotere kiesomschrijvingen en het financieringssysteem van politieke partijen hebben de balans sinds de jaren '60 verder in het voordeel van de partij doen overhellen. Het aantal kiesomschrijvingen voor de Kamer bedraagt voor de grondwetswijziging van 1993 nog 30, tien jaar later resten er nog elf. Door grotere kiesomschrijvingen kunnen partijen hun electorale boegbeelden ruimer inzetten. De keerzijde is dat een lokale machtsbasis aan belang inboet, zowel bij de lijstvorming als bij de kans om verkozen te worden (De Winter, 2005, p. 426). Bovendien ontvangen politieke partijen sinds 1970 overheidssteun, die een steeds groter aandeel van de partijinkomsten is gaan uitmaken. Die financiële middelen (fractietoelagen sinds 1970, partijdotaties sinds 1989) worden niet uitgekeerd aan de individuele parlementsleden, maar aan de centrale partijstructuur overgemaakt (Weekers, Noppe \& Maddens, 2005). Ook hier heeft de partij dus de troeven in handen.

De toegenomen afhankelijkheid van (kandidaat-)parlementsleden van hun partij om (her)verkozen te worden verklaart waarom er eind jaren '90 geen trendbreuk 
waar te nemen is in de dalende gemiddelde ervaring of de stijgende turnover. Formeel gezien komt de Kamer versterkt uit de grondwetswijziging van 1993. Dit zowel ten opzichte van de Senaat - herleid tot een reflectiekamer - als ten opzichte van de regering, die het parlement niet langer naar believen kan ontbinden. De formele versterking van de Kamer tegenover de regering heeft niet geleid tot een stabielere parlementaire elite in die assemblee. Dat is nochtans een te verwachten effect volgens de band die Polsby ziet tussen institutionalisering en circulatie.

Een andere vaststelling is dat, hoewel het regionale beleidsniveau sinds 1995 uit de Kamer verdwenen is, er zich geen duidelijk afgetekend onderscheid tussen federale en regionale parlementaire elite ontwikkeld heeft (Fiers, Gerard \& Van Uytven, 2006, p. 104). Het feit dat verkiezingen voor het federale en regionale niveau sinds 2003 niet meer samenvallen heeft daar weinig aan veranderd, eerder integendeel. De institutionele federalisering - met een rechtstreekse verkozen Vlaams en Waals parlement naast het federale parlement - staat eigenlijk haaks op de confederale structuur van het 'Belgische' partijlandschap. Alle nationale partijen zijn in de loop van de '60 en '70 uiteengevallen in regionale (Vlaamse en Franstalige) 'zusterpartijen'. Aan alle verkiezingen - ongeacht het bestuursniveau - nemen dezelfde, regionale partijen deel. Belgische partijstructuren zijn er niet. De electorale sterkhouders worden door alle partijen steevast bij iedere verkiezing ingezet. Parlementsleden worden als het ware als pionnen verschoven, waar het de partijlogica het beste uitkomt. De Kamer is door de grondwetswijziging uit 1993 niet de centrale politieke assemblee van het federale België geworden. Het federale parlement is nog slechts een schakel in een groter geheel, naast het regionale en Europese niveau, waarbij de partijen als politiek bindmiddel fungeren (Fiers, 2006, pp. 278-280).

Het primaat van de partijlogica boven de institutionele logica heeft een specifiek gevolg voor de parlementaire circulatie, een gevolg dat niet direct is af te lezen uit de grafieken over de gemiddelde ervaring of turnover. De parlementaire circulatie in de loop van de legislatuur is sterk toegenomen. In grafiek 3 wordt de turnover bij verkiezingen en het aantal absolute nieuwkomers tijdens de legislatuur uitgezet als een percentage van het totale aantal kamerleden. De eerste legislatuur (1831-1833) bevat enkel de tussentijdse circulatie, aangezien de vernieuwing bij de eerste verkiezingen in 1831 uiteraard volledig is. Tot 1995 is het aandeel van de vernieuwing tijdens de legislatuur in de regel beperkt. Behalve rond de Wereldoorlogen en tijdens de eerste jaren na de onafhankelijkheid vormt $5 \%$ van het aantal kamerleden zowat de bovengrens. In de negentiende eeuw leidt het ontslag of overlijden van een zetelend kamerlid telkens tot een tussentijdse verkiezing. Sinds de toepassing van de evenredige vertegenwoordiging worden vacante mandaten toegewezen aan 'parlementaire opvolgers'. De invoering van de opvolgers heeft tot doel tussentijdse 
verkiezingen te vermijden en de vacante kamerzetel gaat in principe naar een partijgenoot.

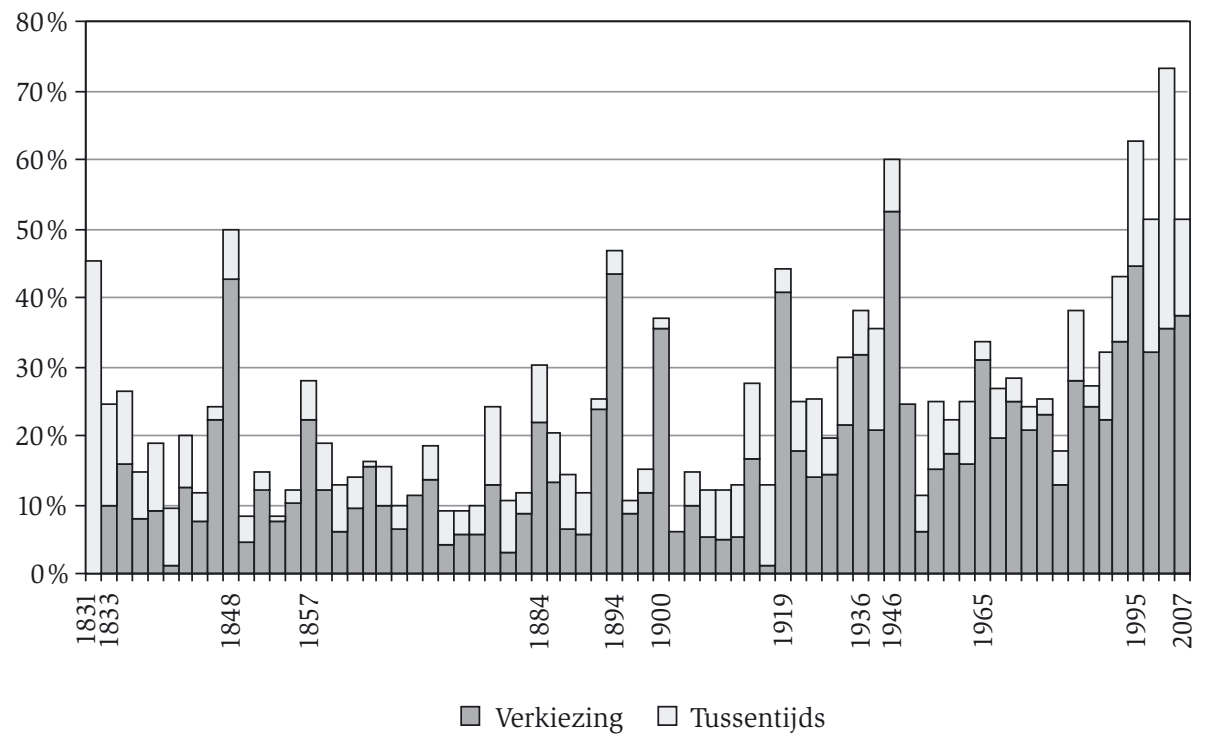

GRAFIEK 3. De turnover en de circulatie tijdens de legislatuur (procentueel ten opzicht van het totale aantal kamerleden), 1831-2008.

De toename van de tussentijdse circulatie is grotendeels te wijten aan level-hopping. Vanaf 1979 vertrekken bij de vijfjaarlijkse Europese verkiezingen telkens een aantal kamerleden naar dat supranationale niveau. De legislatuur 2003-2007 spant qua circulatie de kroon. De verkiezingen brengen meer dan 50 nieuwkomers naar de Kamer (op 150 kamerleden). Maar tot de volgende federale verkiezingen komen nog eens zoveel nieuwkomers via opvolging voor korte of langere tijd in de Kamer. De buitensporig hoge circulatie tijdens deze legislatuur is het gevolg van de eerste regionale verkiezingen (juni 2004) die niet samenvallen met de federale. Veel zetelende federale kamerleden worden door de partijen ingezet op regionale lijsten en verkozen. De hoge tussentijdse circulatie na de verkiezingen van 1995 en 1999 komt er door de opvolging voor parlementsleden die regeringslid worden.

Aan de basis van de hoge tussentijdse vernieuwing liggen weliswaar institutionele factoren: de federalisering van het Belgische parlementaire kader en de parlementaire opvolging van regeringsleden. Maar het is de manier waarop partijen met deze hervormingen zijn omgegaan die het parlementaire circulatiepatroon verklaren. Het bestaan van de opvolgers laat de politieke partijen - die opereren op meerdere 
bestuursniveaus - toe om een actief 'personeelsbeleid' te voeren. Ze spelen hun electorale boegbeelden telkens opnieuw uit, ongeacht het bestuursniveau, en laten hun mandatarissen zonder zetelverlies naar een andere assemblee verschuiven: de vacante zetel blijft in principe bij dezelfde partij. De wijdverspreide praktijk om als parlementslid naar een ander bestuursniveau over te stappen heeft tot kritische vragen geleid over de democratische representativiteit van het Belgische politieke systeem. Aan het eind van de legislatuur 2003-2007 telt de Kamer 56 leden (één op drie) die via opvolging zetelen. Net als bij de eigenlijke kandidatenlijst bepaalt de rangschikking op de opvolgerslijst wie in aanmerking komt om een vacant mandaat op te nemen. De invloed van de lijstsamenstellers is bij de opvolgers nog groter, omdat de kiezers er veel minder gebruikmaken van voorkeurstemmen om deze rangschikking te wijzigen dan bij de eigenlijke kandidaten (Wauters, 2003, pp. 404-406). De vele mandaten via opvolging werd daarom verweten een 'oneigenlijke coöptatie’ door de politieke partijen te zijn (Rimanque, 1999, p. 118).

De wetgever die de opvolgers in 1899 invoerde kon deze praktijk uiteraard niet vermoeden. De politieke praktijk genereert soms onbedoelde gevolgen bij institutionele veranderingen. Zo heeft de grondwetsherziening van 1993 de feitelijke machtspositie van de kamerleden niet versterkt. De parlementaire opvolging van een regeringslid is louter tijdelijk: zodra een kamerlid ontslag neemt uit een regering, moet zijn parlementaire opvolger weer plaatsruimen. Critici noemen de opvolging van ministers een maat voor niets: in plaats van het parlement te versterken tegenover de uitvoerende macht, hebben opvolgers van ministers er helemaal geen baat bij om het de regering moeilijk te maken. De parlementaire opvolging van een minister betekent voor de partijen bovendien een extra te begeven mandaat. Een wet uit 1996 heeft deze regeling nog uitgebreid. Sindsdien krijgt een kamerlid een tijdelijke opvolger, ongeacht het beleidsniveau waarop hij minister wordt (Alen \& Muylle, 2004, pp. 314 \& 326). Partijen hebben het met andere woorden gemakkelijker gemaakt om hun boegbeelden te verschuiven over diverse regeringen, net zoals er bij verkiezingen geschoven wordt tussen parlementen. Na de federale en regionale verkiezingen van juni 1999 is een derde van alle ministers eigenlijk verkozen in een parlement van een ander beleidsniveau (Fiers, 2001).

De grondwetswijziging van 1993 heeft dus niet geleid tot een afgebakende federale en regionale parlementaire elite. Is de gemiddelde ervaring en de circulatie onder de kamerleden dan nog wel voldoende om uitspraken te kunnen doen over de 'Belgische' parlementsleden? Onderstaande tabel bevat opnieuw de spreiding van het aantal verkozenen volgens totale carrièreduur, maar ditmaal zijn alle parlementsleden opgenomen (Kamer en Senaat sinds 1831, het Europese parlement sinds 1979 en de rechtstreeks verkozen regionale parlementen) en wordt gekeken naar de volledige parlementaire carrière, desnoods in meerdere assemblees. Het algemene pa- 
troon vertoont weinig substantiële verschillen met tabel 1, behalve voor de periode sinds de verkiezingen van 1965. Het aandeel van de korte carrières sinds 1965 blijft relatief hoog (39\%), maar is toch minder uitgesproken dan in tabel 1 (bijna 50\%). Door het effect van level-hopping is de verkorting van de gemiddelde Belgische parlementaire loopbaan minder uitgesproken dan uit grafiek 1 zou kunnen blijken. Naast de vele efemere mandaten is er nog steeds een cohorte parlementsleden die een bestendige carrière kunnen opbouwen.

TABEL 2. De spreiding van de parlementsleden volgens duur van het mandaat, absolute aantallen en procenten, 1831-2008.

\begin{tabular}{|c|c|c|c|c|c|c|c|c|c|c|c|}
\hline & \multicolumn{2}{|c|}{$<5 \mathrm{j}}$. & \multicolumn{2}{|c|}{$5-14 j}$. & \multicolumn{2}{|c|}{$15-24 j$} & \multicolumn{2}{|c|}{$25-34 \mathrm{j}}$. & \multicolumn{2}{|c|}{$>34 \mathrm{j}}$. & \multirow{2}{*}{$\begin{array}{c}\text { Totaal } \\
\text { Abs }\end{array}$} \\
\hline & Abs & $\%$ & Abs & $\%$ & Abs & $\%$ & Abs & $\%$ & Abs & $\%$ & \\
\hline $1831-1848$ & 118 & 32,87 & 136 & 37,88 & 65 & 18,11 & 21 & 5,85 & 19 & 5,29 & 359 \\
\hline $1848-1894$ & 184 & 27,02 & 257 & 37,74 & 129 & 18,94 & 73 & 10,72 & 38 & 5,58 & 681 \\
\hline 1894-1919 & 93 & 20,09 & 174 & 37,58 & 126 & 27,21 & 47 & 10,15 & 23 & 4,97 & 463 \\
\hline $1919-1965$ & 382 & 28,30 & 475 & 35,19 & 342 & 25,33 & 124 & 9,19 & 27 & 2,00 & 1.350 \\
\hline $1965-2008$ & 733 & 39,28 & 778 & 41,69 & 295 & 15,81 & 56 & 3,00 & 4 & 0,21 & 1.866 \\
\hline $1831-2008$ & 1.510 & 32,00 & 1.820 & 38,57 & 957 & 20,28 & 321 & 6,80 & 111 & 2,35 & 4.719 \\
\hline
\end{tabular}

\subsection{Parlementaire circulatie na 'regimeonderbrekingen'}

De rol van regimeveranderingen op de werking van het parlementaire systeem is op internationale schaal een logische variabele, met als voorbeeld de vele regimewissels in het negentiende-eeuwse Frankrijk in gedachten, maar lijkt op België amper van toepassing. Grafieken 1 tot 3 bevestigen voor de Kamer wel het beeld dat Best en Cotta (2000, p. 512) en Matland en Studlar (2004, p. 105) schetsen over een beginnend parlementair systeem: een hoge turnover en veel korte carrières maar na verloop van tijd daalt de circulatie en stabiliseert de parlementaire elite. Het eerste decennium na de onafhankelijkheid is het nog een open vraag hoe stabiel de nieuwe Belgische instellingen zullen zijn. Een belangrijke fractie van de adellijke en industriële elite is het nieuwe regime vijandig gezind en het duurt bovendien nog tot 1839 vooraleer de onafhankelijkheid ook internationaal definitief geregeld wordt (Witte, Craeybeckx \& Meynen, 1997). De periode 1831-1848 vertoont effectief een groot aantal korte carrières. Meer dan één op drie van de nieuwe kamerleden zal minder dan vijf jaar zetelen (zie tabel 1). Ook de turnover en de tussentijdse circulatie liggen hoog in het eerste decennium na de onafhankelijkheid. De vele korte carrières worden tussen 1831 en 1848 echter gecompenseerd door 
de stijgende ervaring van de kamerleden die wel een lange loopbaan uitbouwen. Dat laatste blijkt uit grafiek 1: tussen 1831 en 1848 gaat de gemiddelde ervaring ononderbroken in stijgende lijn.

Verder is sinds de redactie van de Belgische grondwet in 1831 de constitutionele positie van het parlement niet of nauwelijks gewijzigd. Enkel de beide Wereldoorlogen komen als regimebreuk in aanmerking, wanneer het Belgische parlementaire werk telkens jaren onderbroken wordt door een Duitse militaire bezetting. Maar parlement en regering doen er in 1918 en 1944 alles aan om zo snel mogelijk de draad weer op te nemen. De vooroorlogse Kamers blijven in functie en nieuwe verkiezingen worden bewust uitgesteld, totdat de normaliteit zoveel mogelijk hersteld is. Dat verklaart waarom de tussentijdse circulatie in de Kamer na de oorlogen plots tot boven $10 \%$ opklimt (zie grafiek 3). Oorlog en bevrijding vormen geen aanleiding voor een nieuwe grondwet, zoals in veel andere Europese landen wel het geval is in de twintigste eeuw.

Toch hebben de beide oorlogen een effect op de parlementaire circulatie. De verkiezingen van 1919 en 1946 worden beide gekenmerkt door een duidelijke daling in de parlementaire ervaring en een grote instroom van nieuwkomers, vergelijkbaar met de vernieuwing in 1848 of 1894 . Het effect van de oorlog is dubbel. Enerzijds zijn er de nieuwe partijverhoudingen. In 1919 komt de BWP op gelijke hoogte met de katholieke partij, mede dankzij het enkelvoudig mannenstemrecht. De cohorte nieuwe socialistische kamerleden leidt tot de tijdelijke daling van de gemiddelde ervaring. Hetzelfde kan gezegd worden over 1946, wanneer de communisten (tijdelijk) doorbreken en in zetelaantal de liberale partij voorbijsteken. Anderzijds blijkt de oorlog ook een katalysator voor een interne partijvernieuwing. Dat verklaart het grote katholieke aandeel in de vernieuwing onder de kamerleden in 1946. De CVPPSC stuurt dat jaar maar liefst 59 nieuwkomers naar de Kamer (op 92 verkozenen). Opgericht in 1945, wil de CVP-PSC de breuk met het verleden onderlijnen. De partij neemt afstand van de kaders van de vooroorlogse katholieke partij en beoogt een grondige vernieuwing onder de parlementsleden (Kwanten, 2001, pp. 309-312). Een van boven opgelegde vernieuwing van de parlementaire vertegenwoordiging is op dat ogenblik nog niet vanzelfsprekend. De uitzonderlijke omstandigheden (een nieuwe partij, de erfenis van de oorlogsjaren en de oppositiekuur) helpen echter. Feitelijk voltrekt zich een analoog scenario na de Eerste Wereldoorlog, maar ditmaal komt de dynamiek nog van onderuit. Katholieke flaminganten en de Christelijke Arbeidersbeweging nemen in Vlaanderen de katholieke kiesverenigingen uit handen van de conservatieve vooroorlogse generatie en eisen hun plaats op bij de opmaak van de kieslijsten (Gerard, 1985). De katholieke vernieuwing in 1919 (22 nieuwkomers op 73 verkozenen) komt echter onvoldoende uit de verf in grafiek 2, omdat de partij dat jaar bijna twintig kamerzetels verliest. 


\section{Conclusies}

Eerder onderzoek heeft al uitgewezen dat de dalende leeftijd van parlementsleden en kortere parlementaire carrières tot de belangrijkste tendensen in de naoorlogse parlementaire vertegenwoordiging behoren, naast de vervrouwelijking en een gewijzigde sociografische samenstelling (Fiers, 2006). De gegevens over de parlementaire circulatie in de Belgische Kamer van volksvertegenwoordigers plaatsen die vaststellingen in een ruimer tijdsperspectief. De Belgische parlementaire elite consolideert zich in het eerste decennium na de onafhankelijkheid. Het patroon dat zich midden negentiende eeuw onder de kamerleden ontwikkelt - een relatief lage circulatie, gemiddelde carrières van 10 tot 12 jaar - houdt grosso modo aan tot de jaren 1960. Daarna volgt een tendens van gemiddeld kortere carrières, maar het gemiddelde maskeert een stabiel aandeel van mandaten tussen vijf en vijftien jaar. De aanwezigheid van een stabiele parlementaire elite, die de hoge circulatie compenseert, is nog meer uitgesproken wanneer rekening gehouden wordt met het effect van level-hopping.

Mutaties in de partijwerking en dan vooral de toenemende afhankelijkheid van parlementsleden tegenover hun politieke partij inzake hun herverkiezing lijkt van doorslaggevend belang te zijn voor de evolutie op langere termijn. Institutionele hervormingen laten duidelijk sporen na, maar telkens gaat het om tijdelijke schokken. De parlementaire onverenigbaarheden van 1848 zijn hiervan een duidelijk voorbeeld. Ook de grondwetswijziging van 1993 leidt in 1995 niet tot een ombuiging van de circulatiepatronen. Hervormingen aan het stemrecht en het kiessysteem eind negentiende eeuw markeren weliswaar een overgangsperiode, maar dan omdat de electorale partijverhoudingen wijzigen. Hetzelfde kan gezegd worden over het effect van de eerste naoorlogse verkiezingen. Over de langere termijn treedt er geen ander patroon op na de invoering van de evenredige vertegenwoordiging. Nog een opmerkelijke vaststelling: de doorbraak van de BWP vormt evenmin een cesuur. De door Best en Cotta veronderstelde tegenstelling tussen massapartijen en negentiende-eeuwse (kader)partijen blijkt inzake parlementaire circulatie niet op te gaan. De tendens naar kortere parlementaire carrières komt er pas wanneer partijen na de Tweede Wereldoorlog zich (mede dankzij overheidssteun) tot professionele organisaties omvormen, het ideologische keurslijf lossen en het volledige electoraat gaan bespelen.

In navolging van Hibbings kritiek op Polsby gaan we ervan uit dat de parlementaire circulatie op zich ons niet veel kan zeggen over de institutionalisering van de Belgische Kamer van volksvertegenwoordigers. Daarvoor zijn andere indicatoren nodig (werking van het commissiesysteem, de evolutie van het kamerreglement enzovoort). Indirect kan er wel iets gezegd worden over de werking van het parle- 
mentaire systeem, aangezien het carrièrepatroon mede functie is van het type - in de terminologie van Best en Cotta - selectorate (Best \& Cotta, 2007, pp. 14-15). Met andere woorden: hoe binnen een politieke partij de kieslijsten opgemaakt worden bepaalt ook de positie van het parlementslid tegenover zijn partij. Hoewel het Belgische parlement al direct na de Eerste Wereldoorlog verweten wordt in crisis te zijn en latere auteurs de particratie aan het werk zien in het interbellum, worden de traditionele partijen tot na de Tweede Wereldoorlog gekenmerkt door een stabiele parlementaire elite (Gerard, 2005; Balthazar, 1981; Perin, 1960). Interne (centralisering ten nadele van de lokale federaties, leeftijds- en andere beperkingen) en externe (grotere kiesomschrijvingen, partijdotaties, nationalisering van verkiezingen) factoren hebben de balans na de Tweede Wereldoorlog in het nadeel van de individuele parlementsleden doen overhellen.

\section{Noten}

1. Overige partijen: Daensisten, Frontpartij, VNV, communisten, Rex, Volksunie, FDF, RW, Vlaams Blok/Belang, Ecolo, Agalev/Groen!, N-VA, LDD, FN, RAD, afzonderlijken.

2. Statuts du POB en vigueur au 10-5-1940, Brussel, s.d., p. 21. Bewaard in het Institut Emile Vandervelde, Brussel.

3. Archieven van de liberale partij, notulen nationale partijorganen, 1961 \& 1963. Bewaard in het Centre Jean Gol, Brussel.

4. 21e Nationaal Congres van de CVP. Voorstellen tot wijziging van statuten. Luik, 1819 december 1965, s.1., 1965.

\section{Bibliografie}

Alen, A. \& Muylle, K. (2004). Compendium van het Belgisch staatsrecht. Mechelen: Kluwer.

Balthazar, H. (1981). De ontwikkeling van de particratie vóór de Tweede Wereldoorlog. Res Publica, 23 (1), 9-22.

Best, H. \& Cotta, M. (Eds.) (2000). Parliamentary Representatives in Europe 1848-2000. Legislative Recruitment and Careers in Eleven European Countries. Oxford: Oxford University Press. 
Cotta, M. \& Best, H. (Eds.) (2007). Democratic Representation in Europe. Diversity, Change and Convergence. Oxford: Oxford University Press.

Caramani, D. (2004). The Nationalization of Politics. The Formation of National Electorates and Party Systems in Western Europe. Cambridge: Cambridge University Press.

Ceuleers, J. (1974). De lijstensamenstelling in de BSP. Res Publica, 16 (3-4), 373-386.

Debuyst, F. (1967). La fonction parlementaire en Belgique. Mécanismes d'accès et images. Brussel: CRISP.

Dechesne, M. (1974). Le parti libéral à Liège 1848-1899. Leuven: Nauwelaerts.

Delwit, P. \& De Waele, J-M. (1996). Ecolo. Les verts en politique. Brussel: De Boeck.

Depauw, S. (2002). Rebellen in het Parlement. Fractiecohesie in de Kamer van Volksvertegenwoordigers (1991-1995). Leuven: Universitaire Pers Leuven.

Deschouwer, K. (1993). Organiseren of bewegen? De evolutie van de Belgische partijstructuren sinds 1960. Brussel: VUBPress.

Deschouwer, K. (1999). From Consociation to Federation. How the Belgian Parties Won. In K. Luther \& K. Deschouwer. (Eds.), Party Elites in Divided Societies. Political Parties in Consociational Democracy (pp. 74-107). Londen: Routledge.

Dewachter, W. (1969). CVP en PSC in 1969 of het testen van de sterkte der partiggrenzen. In Belgische Politiek 1969 (pp. 61-93). Brussel: Belgisch Instituut voor Wetenschap der Politiek.

Dewachter, W. (2001). De mythe van de parlementaire democratie. Een Belgische analyse. Leuven: Acco.

De Winter, L. (1980). Twintig jaar polls, of de teloorgang van een vorm van interne partijdemocratie. Res Publica, 22 (4), 563-585.

De Winter, L. (2005). Belgium: Empowering Voters or Party Elites? In M. Gallagher \& P. Mitchell (Eds.), The Politics of Electoral Systems (pp. 417-432). Oxford: Oxford University Press.

Dogan, M. (2003). Longévité des carrières politiques. Une biographie collective. In J-M. Mayeur, J-P. Chaline \& A. Corbin (Eds.), Les parlementaires de la Troisième République (pp. 295-325). Parijs: Publications de la Sorbonne.

Duverger, M. (1951). Les partis politiques. Parijs: Librairie Armand Colin.

Fiers, S. (2000). Vijftig jaar volksvertegenwoordiging. De circulatie onder de Belgische parlementsleden 1946-1995. Brussel: Koninklijke Vlaamse Academie van België voor Wetenschappen en Kunsten.

Fiers, S. (2001). Carrièrepatronen van Belgische parlementsleden in een Multi-level omgeving (1979-99). Res Publica, 43 (1), 171-192.

Fiers, S. (2006). Evoluties in het parlementaire stelsel. In E. Witte \& A. Meynen (Eds.), De geschiedenis van België na 1945 (pp. 263-288). Antwerpen: Standaard Uitgeverij.

Fiers, S., Gerard, E. \& Van Uytven, A. (2006). De uitverkorenen. De federale en Vlaamse parlementsleden (1946-2004). In S. Fiers \& H. Reynaert (Eds.), Wie zetelt? De gekozen politieke elite in Vlaanderen doorgelicht (pp. 87-111). Leuven: Lannoo Campus. 
Fiers, S. \& Gubin, E. (2003). De fysionomie van de Kamer van Volksvertegenwoordigers. In E. Gerard, E. Witte, E. Gubin \& J-P. Nandrin (Eds.), Geschiedenis van de Belgische Kamer van Volksvertegenwoordigers 1830-2002 (pp. 89-128). Brussel: Kamer van Volksvertegenwoordigers.

Geldolf, W. (2006). Een stuk oude politieke cultuur achteraf bekeken. Antwerpen: De Vries-Brouwers.

Gerard, E. (1985). De katholieke partij in crisis. Partijpolitiek leven in Belgie 1918-1940. Leuven: Kritak.

Gerard, E. (2005). 'Een schadelijke instelling'. Kritiek op het parlement in België in het interbellum. Bijdragen en Mededelingen betreffende de Geschiedenis der Nederlanden, 120 (3), 497-512.

Govaerts, J. (1997). Een sociaal-politieke studie van de volksvertegenwoordigers van de arrondissementen Antwerpen, Mechelen en Turnhout (1870-1912). Onuitgegeven licentieverhandeling, Departement Geschiedenis, Katholieke Universiteit Leuven.

Graham, J. (1982). Legislative Careers in the French Chamber and U.S. House 18711940. Legislative Studies Quarterly, 7 (1), 37-56.

Hazan, R. \& Rahat, G. (2006). The Influence of Candidate Selection Methods on Legislatures and Legislators. Theoretical Propositions, Methodological Suggestions and Empirical Evidence. Journal of Legislative Studies, 12 (3-4), 366-385.

Hibbing, J. (1999). Legislative Careers. Why and How we Should Study Them. Legislative Studies Quarterly, 24 (2), 149-171.

Kwanten, G. (2001). August-Edmond De Schryver (1898-1991). Politieke biografie van een gentleman-staatsman. Leuven: Universitaire Pers Leuven.

Leus, K. \& Veny, L. (Eds.) (1996). Het federale België in de praktijk. De werking van de wetgevende vergaderingen na de verkiezingen van 21 mei 1995. Brugge: die Keure.

Matland, R. \& Studlar, D. (2004). Determinants of Legislative Turnover. A Cross-National Analysis. British Journal of Political Science, 34, 87-108.

Mommen, A. (1974). Een aspect van het reformisme: de Belgische Werkliedenpartij en haar liberale connectie (1889-1894). Belgisch Tijdschrift voor Nieuwste Geschiedenis, 5 (3-4), 273-338.

Norris, P. (Eds.) (1997). Passages to Power. Legislative Recruitment in Advanced Democracies. Cambridge: Cambridge University Press.

Norton, P. (2005). Parliament in British Politics. Basingstoke: Palgrave.

Perin, F. (1960). La démocratie enrayée. Essai sur le régime parlementaire belge de 1918 à 1958. Brussel: Institut Belge de Science Politique.

Pilet, J-B. (2007). Changer pour gagner? Les réformes des lois électorales en Belgique. Brussel: Editions de l'Université de Bruxelles.

Polsby, N. (1968). The Institutionalization of the U.S. House of Representatives. American Political Science Review, 62 (1), 144-168.

Power, T. \& Rae, N. (Eds.) (2006). Exporting Congress? The Influence of the U.S. Congress on World Legislatures. Pittsburgh: University of Pittsburgh Press. 
Rimanque, K. (1999). De grondwet toegelicht, gewikt en gewogen. Antwerpen: Intersentia.

Rush, M. (2004). From Gentlemen to Players. The Role of the Member of Parliament Since 1868. Oxford: Oxford University Press.

Somit, A., Wildenmann, R., Boll, B. \& Römmele, A. (Eds.) (1994). The Victorious Incumbent. A Threat to Democracy? Aldershot: Dartmouth.

Stengers, J. (1990). Caractères généraux de l'évolution du Sénat depuis 1831. In La réforme du Sénat (pp. 11-43). Brussel: ULB \& Bruylant.

Stengers, J. (2000). L'établissement de la représentation proportionnelle en Belgique en 1899. In P. Delwit \& J-M. De Waele (Eds.), Le mode de scrutin fait-il l'élection? (pp. 129-143). Brussel: Editions de l’Université de Bruxelles.

Van Braband, S. (2003). De Belgische parlementsverkiezingen van 26 juni 1949 en 4 juni 1950. Polarisatie rond de Koningskwestie. Onuitgegeven licentieverhandeling, Departement Geschiedenis, Katholieke Universiteit Leuven.

Van Den Berg, J. (1983). De toegang tot het Binnenhof. De maatschappelijke herkomst van de Tweede-Kamerleden tussen 1849 en 1970. Weesp: Van Holkeman en Warendorf.

Walkland, S. (Eds.) (1979). The House of Commons in the Twentieth Century. Essays by Members of the Study of Parliament Group. Oxford: Clarendon Press.

Wauters, B. (2003). Het gebruik van voorkeurstemmen bij de federale parlementsverkiezingen van 18 mei 2003. Res Publica, 45 (2-3), 401-428.

Weber, D. (2003). 'La marche des opérations électorales'. Bepalingen rond kiesverrichtingen in de Belgische kieswetgeving, 1830-1940. Belgisch Tijdschrift voor Filologie en Geschiedenis, 81 (2), 311-342.

Weekers, K., Noppe, J. \& Maddens, B. (2005). 35 jaar overheidsfinanciering van politieke partijen in België (1970-2004). Tijdschrift voor Bestuurswetenschappen en Publiek Recht, 60 (7), 477-465.

Witte, E. (1981). Het Belgische ambtenarenparlement. Belgisch Tijdschrift voor Filologie en Geschiedenis, 59 (3), 828-882.

Witte, E., Craeybeckx, J. \& Meynen, A. (Eds.) (1997). Politieke geschiedenis van België van 1830 tot heden. Antwerpen: Standaard Uitgeverij. 